\title{
THE RELATIONSHIP BETWEEN CAREER PATTERNS AND PERSONALITY TYPES
}

\author{
M COETZEE \\ AMG SCHREUDER \\ Department of Industrial Psychology \\ University of South Africa
}

\begin{abstract}
Contemporary career research emphasises the need for career counselling practices that will assist individuals in shifting from linear career preferences to non-linear career patterns. A Career counselling framework that facilitates self-insight in personal motives and personality preferences seems to enable individuals to develop the inner sense of direction and identity required to view new career patterns as challenges for personal growth. The aim of this study was to examine the relationship between career patterns and personality types in an attempt to contribute to the development of such a career counselling framework. The trends in the literature survey offered support, whilst the results of the empiral study were less supportive. Recommendations are made on the basis of these findings.
\end{abstract}

\section{OPSOMMING}

Hedendaagse loopbaannavorsing beklemtoon die behoefte aan loopbaanberadingspraktyke wat individue kan help om die verskuiwing van liniêre loopbaanvoorkeure na nie-liniêre loopbaanpatrone te maak. 'n Loopbaanberadingsraamwerk wat selfinsig in persoonlike motiewe en persoonlikheidsvoorkeure fasiliteer blyk individue te help om die innerlike gevoel van rigting en identiteit te ontwikkel om nuwe loopbaanpatrone as uitdagings vir persoonlike groei te beskou. Die oogmerk met hierdie studie was om die verband tussen loopbaanpatrone en persoonlikheidstipes te ondersoek in 'n poging om 'n bydrae te lewer tot die ontwikkeling van sodanige loopbaanberadingsraamwerk. Die strekking van die literatuurondersoek bied ondersteuning, terwyl die resultate van die empiriese studie minder ondersteunend is. Aanbevelings word op grond van die bevindinge gemaak.

Careers research has recently been much absorbed with the radical changes to employment brought about by the information revolution and the globalizing of the economy. Various authors observed that organisational structures are becoming flatter and leaner, and in turn traditional career paths are becoming less stable. There is a shifting emphasis towards limited linear and more alternative routes of career progression; interorganisational instead of intra- organisational movements and a more employer independent career indentity. Job security is also defined in terms of being employable and not by being employed. (Galbraith, 1993; Hiltrop, 1995; Mirvis \& Hall, 1994; Moss Kanter, 1994; Peiperl, Arthur, Goffee \& Morris, 2000; Weick, 1996).

Contemporary ideas about the organising of work, whether they emphasise dynamic inter-company network arrangements or decentralised, individualised corporations, rely on the individual's ability to learn and adapt rather than perform as required (Ghoshal \& Bartlett, 1997; Handy, 1989; Miles \& Snow, 1994; Peiperl et al, 2000). In a complex world of oftenshifting work arrangements, people are encouraged to take ownership of their careers and to act on the ambiguity they experience (DeFillippi \& Arthur, 1994). Career choice and development practices within the organisation need to shift from facilitating career decision-making to assisting individuals in career and work adjustment, or adaptation. Various authors have suggested in this regard a need for an overarching conceptual career counselling framework which will provide the industrial psychologist with either a theoretical or practical base to devise better means for matching clients to career interventions needed in the new world of work (Brooks, 1991; Driver, 1985; Montross \& Shinkman, 1992; Peiperl et al, 2000; Savickas, 1994).

It appears that both the Career Concepts Model of Driver (1979) and Jung's (1990) theory of personality types can make an additional contribution to enhance individual self-insight in career experiences and preferences. The Career Concepts Model of Driver (1979) addresses the three-way fit between individual career patterns, organisational forces and societal trends. It provides a conceptual framework of career alterna-

Requests for copies should be addressed to: A. M. G. Schreuder, Department of Industrial Psychology, UNISA, POBox 392, UNISA, 0003 tives (linear versus non-linear career tracks) linked to individual differences in key motives and values. It allows for selfassessment activities to enhance self-insight and informed choice to facilitate career adjustment, or adaptation. Jung's (1990) theory of personality types provides a framework for understanding personality differences in cognitive and perceptual styles, motives and values in career decision-making. It also allows for self-assessment activities to enhance self-insight and informed choice in facilitating career adjustment, or adaptation.

Research by Driver (1982), Olson (1979), and Prince (1979) indicate a relationship between Schein's (1975) career anchors and the career patterns described in Driver's (1979) Career Concepts Model. Research by Van Vuuren (1989) found a relationship between Schein's (1975) career anchors and personality and concluded that specific career anchors ought to have specific personality profiles. Hendrickz (1987) indicates a linkage between Schein's (1975) career anchors and Holland's (1985) occupational types. Kummerow (1991) found specific relationships between Holland's (1985) occupational types and the personality types described in Jung's (1990) theory of personality types.

Given the relationship between career anchors and personality, as well as the relationship between career anchors and career patterns, this study aimed to examine the relationship between the career patterns described in the Career Concepts Model (Driver, 1979) and the personality types described by Jung (1990).

A relationship between personality types and career patterns may help to give perspective to the theoretical and practical value of the Career Concepts Model within a changing world of work. If such a relationship does exist, it may be postulated that personality types can act as predictors for specific career patterns. Furthermore, such an endeavour would provide intruiging insights in developing an overarching framework for career choice and development practices within the context of the current and future organisational realities, especially a framework that can be linked to individual differences in cognitive and perceptual styles, motives, values and career patterns. 


\section{The Career Concepts Model}

It appears that the individual's definition of career success by way of a preferred career pattern- a concept developed by Driver (1979) - can make an additional contribution to matching internal career needs of individuals and external career opportunities. Driver $(1979,1985)$ defines a career pattern as an enduring cognitive or conceptual structure underlying the individual's thinking concerning his or her career. This underlying cognitive structure defines the meaning of a career for the individual. The career pattern may be conscious or subconscious. In either case, it is seen to function like an inner gyroscope governing the individual's career moves. Furthermore, career decisions are guided by specific career decision factors or personal motives which form an integral part of the career pattern (Driver, 1979; Driver \& Sundby, 1983).

The combination of three definitional components (frequency of change in career areas, direction of movement, job content changes) into various patterns produces various pictures of career behaviour ranging from stayers to movers of various frequencies, and from vertical to lateral movement. In a theoretical framework these four patterns may be thought of as the operational definitions of four constructs defined as linear, expert, spiral, and transitory (Coombs, 1989). Each of these four career patterns describes a fundamentally different career pattern, each with a unique conceptualisation of career success. Table 1 presents the key features of each of these four basic career patterns (Brousseau, 1990; Brousseau \& Driver, 1994; Driver \& Sundby, 1983; Driver, 1985).

TABLE 1

OVERVIEW OF THE FOUR CAREER PATTERNS AS ALTERNATIVE VIEWS OF THE IDEAL CAREER

\begin{tabular}{|c|c|c|}
\hline Career Pattern & Frequency of field change & Direction of movement \\
\hline Linear & $\begin{array}{l}\text { ^Infrequent } \\
\text { ^Mobility mostly } \\
\text { limited to }\end{array}$ & $\begin{array}{l}\text { ^Upward } \\
\star \text { Person moves upward rapidly } \\
\text { to positions of higher authority }\end{array}$ \\
\hline Expert & $\begin{array}{l}\text { ^No change } \\
\star \text { Person remains within }\end{array}$ & $\begin{array}{l}\star \text { Minimal upward movement } \\
\text { ^Person stays in one position or } \\
\text { makes two or three moves } \\
\text { upward within a specialty of } \\
\text { function }\end{array}$ \\
\hline Spiral & $\begin{array}{l}\star \text { Every five to ten years } \\
\text { ^Person makes a major } \\
\text { or occupation }\end{array}$ & $\begin{array}{l}\text { ^Lateral } \\
\text { ^Person moves into new type of } \\
\text { work that builds on current } \\
\text { skills and develops new ones. }\end{array}$ \\
\hline Transitory & $\begin{array}{l}\star \text { Every two to four } \\
\text { years } \\
\text { ^Person makes frequent }\end{array}$ & $\begin{array}{l}\text { ^Mainly lateral } \\
\text { ^"Consistently inconsistent" } \\
\text { pattern. More lateral than } \\
\text { upward. }\end{array}$ \\
\hline
\end{tabular}

According to Brousseau (1990), different types of careers offer different types of rewards and opportunities to satisfy different work-related needs. Studies by Coombs (1989); Driver and Sundby (1983); and Prince (1979) have found individuals' work values to correlate with their ideal career patterns.

These studies indicate that each of the career patterns is associated with several values that seem to represent the motivation for that particular career pattern. These findings are supported by research (Driver, 1979, 1982, 1985; Driver \& Coombs, 1983; Olson, 1979) which have identified linkages between the four career patterns and various motivating factors for various populations or groups. Just as there are differences in the stability and duration of time in a chosen field, it has been found (in the research) that there are distinct differences in particular motives of individuals who follow each of the career patterns. These motives may be seen to form an integral part of the career pattern. Table 2 gives an overview of the key motives most commonly linked to the career patterns.

Discrepancies between ideal career patterns and career pattern motives indicate the extent to which socialization processes (at work or elsewhere) have influenced individuals to view the appropriateness of various career paths in ways that differ from what would be the case if their perceptions were influenced only by their own personal motives. Ideal career patterns refer to the social desirability of a specific career pattern, whereas the career pattern motives refer to individuals' true career pattern preferences (Brousseau, 1990).

TABLE 2

CAREER PATTERN MOTIVES

\begin{tabular}{llll}
\hline Linear & Spiral & Expert & Transitory \\
\hline Power & Personal growth & Expertise & Variety \\
Competence & Creativity & Security & Independence \\
Achievement & Developing others & Competence & Creativity \\
Management & Prestige & Stability & People \\
Recognition & Recognition & Autonomy & Involvement \\
Self-development & & Achievement & Achievement \\
\hline \multicolumn{2}{c}{ (Adapted from: Brousseau, 1990; Brousseau \& Driver, 1994) }
\end{tabular}

Mismatches between individual's ideal career patterns and personal career motives (or true career patterns), allow for facilitating the shift from linear career preferences to the non-linear career patterns. Career awareness training and counselling on mismatching ideal career patterns and career pattern motives, actually validate the non-linear career patterns (Brousseau, 1990).

\section{Personality Type Theory}

According to Jung (1990), each personality may be divided into one of various personality types in terms of two constructs, namely attitudes and functions.

The two basic attitudes in Jung's typology are extraversion and introversion. Extraversion is being described as an outgoing, candid and accommodating nature that adapts easily to a given situation, quickly forms attachments, and, setting aside any possible misgivings, often ventures forth into an unknown situation. Introversion implies a hesitant, reflective, retiring nature that keeps itself to itself, shrinks from objects, is always slightly on the defensive, and prefers to hide mistrustful scrutiny (Jung, 1990).

The two attitudes do not represent a dichotomy. Every personality has both introvert and extrovert characteristics. However, in every personality one attitude, for example extraversion, is dominant and conscious, while the other attitude is subordinate and unconscious. The subordinate attitude compensates for the dominant attitude and vice versa.

Jung's (1990) theory of personality types is concerned with the conscious use of the functions, of perception and decision making (or judgment) and the areas of life is which these functions are used. Jung (1990) assumes that apart from a dominant attitude, each person also has a specific way in which he/she observes his/her world and assigns meaning to each experience. He distinguishes four such conscious mental functions, or processes, namely: two perception processes (sensing and intuition) and two judgment processes (thinking and feeling). By combining an individual's dominant attitude and function, the basic personality type may be determined. The personality types are thus patterns in the way people prefer to perceive and make judgments.

Myers (1980) extended Jung's (1990) theory on personality types by including the presence of an auxiliary process to supply a degree of balance between the functions of perception and judgment, and the attitudes of extraversion and introversion.

Jung (1990) based his theory on clinical observations and consequently portrays each mental process in sharpest focus and with maximum contrast between its extraverted and introverted forms. Jung (1990) thus describes the rare, theoretically "pure" types (Myers, 1980). Myers (1980) developed an instru- 
ment, called the Myers-Briggs Type Indicator, to make it possible to empirically test and use Jung's theory with nonclinical populations.

Myers (1980) theory on personality types distinguishes between sixteen personality types. Tables 3 and 4 highlight the strengths of each personality type, and the similarities and differences of the sixteen personality types (Lawrence, 1993).

The MBTI questionnaire items are concerned with four bipolar preferences to determine the relative preference of one over the other. The four scales correspond to the four dimensions of Personality Type theory, as shown in Table 3. The MBTI uses a shorthand designation for the eight characteristics as in the figure.

For the purpose of this research project, the SN and TF indices were of interest. The $\mathrm{SN}$ and TF indices represent the individual's orientation to consciousness and are referred to as orientating functions (Myers \& McCaulley, 1992). Combinations of perception ( $\mathrm{S}$ and $\mathrm{N}$ ) with judgment ( $\mathrm{T}$ and $\mathrm{F}$ ) give four groupings of personality types, namely Sensing-Thinking (ST); Sensing-Feeling (SF); Intuition-feeling (NF) and Intuition-Thinking (NT) types. Each personality type has specific characteristics which are assumed to stem from the preferred use of the mental functions.

Myers and McCaulley (1992) considered these four personality type groupings as the most important of the groupings of the types, particularly when career choices are concerned.

The various personality types differ in their interests, values and needs. They learn in different ways and cherish different occupations (Myers, 1980).

TABLE 3

FOUR PREFERENCES ARE SCORED TO ARRIVE AT A PERSON'S PERSONALITY TYPE

Does the Person's Interest flow Mainly To

The Outer World

E of Actions, Objects

and Persons?

EXTRAVERSION

The Inner World

of Concepts

and Ideas?

\section{INTROVERSION}

\begin{tabular}{|c|c|c|c|}
\hline \multicolumn{4}{|c|}{ Does the Person Prefer To Perceive } \\
\hline \multirow{4}{*}{$\mathrm{S}$} & The Immediate, Real & The Possibilities, & \\
\hline & Practical Facts of & Relationships and & \\
\hline & Experience and Life? & Meanings of Experiences? & $\mathrm{N}$ \\
\hline & SENSING & INTUITION & \\
\hline \multicolumn{4}{|c|}{ Does the Person Prefer to make Judgements or Decisions } \\
\hline \multirow{5}{*}{$\mathrm{T}$} & Objectively, Impersonally, & Subjectively and & \\
\hline & Considering Causes of & Personally, Weighing & $\mathrm{F}$ \\
\hline & Events \& Where Decisions & Values of Choices \& How & \\
\hline & May Lead? & They Matter to others? & \\
\hline & THINKING & FEELING & \\
\hline
\end{tabular}

Does the Person Prefer Mostly to Live

In a Decisive, Planned and Orderly In a Spontaneous, Flexible

J Way, Aiming to Regulate and

Way, Aiming to

Understand Life and Adapt to it?

\section{JUDGEMENT}

PERCEPTION

(Adapted from : Lawrence, 1993)

TABLE 4

BRIEF DESCRIPTION OF THE SIXTEEN PERSONALITY TYPES

$$
\text { ENTJ }
$$

Intuitive, innovative Organizer, analytical, systematic, confident; pushes to get action on new ideas and challenges.
ESTJ

Fact-minded, practical Organizer, assertive analytical, systematic, pushes to get things done and working smoothly and efficiently.

\section{INTP}

Inquisitive Analyzer, reflective, independent, curious: more interested in organizing ideas than situations or people.

\section{ISTP}

Practical Analyzer, values exactness: more interested in organizing data than situations or people; reflective, a cool and curious observer of life.

\section{ESTP}

Realistic Adapter in the world of material things; good natured, tolerant, easy going; oriented to practical, first hand experience; highly observant of details of things.

\section{ESFP}

Realistic Adapter in human relationships; friendly and easy with people, highly observant of their feeling and needs: orientated to

\section{ISTJ}

Analytical Manager of Facts and Details; dependable, decisive, painstaking and systematic: concerned with systems and organization; stable and conservative.

\section{ISF}

Sympathetic Manager of Facts and Details, concerned with people's welfare, dependable, painstaking and systematic; stable and conservative.

(Adapted from : Lawrence, 1993) practical, first hand experience.

\section{INFP}

Imaginative, independent Helper, reflective, inquisitive, empathic, loyal to ideals, more interested in possibilities than practicalities.

ESFJ

Practical Harmonizer and workerwith-people; sociable, orderly, opinioned; conscientious; realistic and well tuned to the here and now.

\section{ENFJ}

Imaginative Harmonizer and worker-with people; sociable, expressive, orderly, opinioned, conscientious, curious about new ideas and possibilities.

\section{INFJ \\ People-oriented Innovator of ideas; serious, quietly forceful and persevering; concerned with the common good, with helping others} develop.

\section{INTJ}

Logical, critical, decisive Innovator of serious, intent, highly independent, concerned with organization; determined and often stubborn.
According to Personality Type theory, one of the most important motivations for career choice is a desire for work that is intrinsically interesting and satisfying and that will permit use of preferred functions and attitudes (Myers \& McCaulley, 1992). Knowledge and understanding of Personality Type theory give individuals a sense of worth and dignity concerning their own qualities. Individuals can be aided in expanding their choices by helping them to realise their strengths and to develop their less preferred functions. New tasks, jobs or careers can be made more palatable if they are construed as challenges for personal growth. Cultivating new and different career patterns can actually become a good arena for personality type development (Myers \& McCaulley, 1992).

Against the aforementioned background, this research project attempted to determine whether linkages exist between the linear, spiral, transitory and expert career patterns as explained in the Career Concepts Model of Driver (1979), and the ST, SF, $N F$ and NT personality types as defined by Myers (1980).

Based on the approaches of Driver (1982); Olson (1979); Prince (1979); Van Vuuren (1989); Hendrickz (1987) and Kummerow (1991), the following linkages between the linear, transitory, expert and spiral career patterns and ST, SF, NF, NT personality types are postulated: 
The expert career pattern may associate with the ST and SF personality types (ISTP, ESTP, ISTJ, ESTJ, ISFJ, ESFJ, ISFP, ESFP) as they apparently share the same underlying work values of expertise, security, stability. The linear career pattern may associate with the ST and NT types (ISTP, ESTP, ISTJ, ESTJ, INTJ, ENTJ, INTP, ENTP), as they seemingly share the underlying work values of performance, power, and achievement. Finally the spiral and transitory career patterns may associate with the NT and NF personality types (INTJ, ENTJ, INTP, ENTP, INFJ, ENFJ, INFP, ENFP) as they seemingly share the underlying work values of personal growth, developing others, variety, autonomy and creativity.

\section{METHOD}

\section{Hypotheses}

The specific research hypotheses are as follows

Hol - There is no relationship between career patterns and personality types.

H1 - There is a relationship between career patterns and personality types.

\section{The participants}

The population was limited to a single organisation. Based on Brousseau's (1990) and Brousseau and Driver's (1994) assertion that non-linear career awareness should be stimulated among managerial and professional levels of staff, the decision was made to sample the chosen organisation's managerial levels of staff (which include middle managers and supervisors) and the professional levels of staff. The professional levels of staff function on the same level as the managerial group of people in terms of organisational decision-making. Table 5 gives an overview of the initial and final sample sizes per group.

TABLE 5

INITIAL AND FINAL SAMPLE SIZES PER OCCUPATIONAL GROUP

\begin{tabular}{rrcr}
\hline Questionnaires & $\begin{array}{c}\text { Questionnaires } \\
\text { returned \& used } \\
\text { Occupational Group }\end{array}$ & (n) \\
& sent out (n) & 1 & 100 \\
Accountant & 1 & 2 & 100 \\
Chemical Analyst & 2 & 16 & 62 \\
Engineers & 26 & 4 & 67 \\
Human Resources Practitioner & 6 & 8 & 100 \\
Instructor (Technical) & 8 & 16 & 57 \\
Manager (Technical) & 28 & 1 & 25 \\
Manager (Non-technical) & 4 & 10 & 100 \\
Planner & 10 & 44 & 68 \\
Supervisor (Technical) & 65 & 3 & 100 \\
Supervisor (Non- Technical) & 3 & 20 & 43 \\
Technician & 47 & $\mathbf{1 2 5}$ & $\mathbf{6 2 , 5}$ \\
\hline TOTAL & $\mathbf{2 0 0}$ & &
\end{tabular}

According to this table the number of technically orientated $(92,8 \%)$ occupations outnumbered the non-technical occupations $(7,2 \%)$ significantly, as expected in such a technically oriented organisation.

In summary, the participants can be described as follows: The mean age of the respondents was 35,36 years, and with males being the majority group (96,8\%). A first significant characteristic was the work stability of the sample group: $56,8 \%$ had 5 to 10 years of service with the organisation, and 22,4\%, 10 to 15 years of service. A second significant characteristic was the high technically oriented $(92,8 \%)$ occupations. Both Managers and Supervisors (48\%) were predominantly from a technical background. These characteristics of the sample group were taken into account in the interpretation and generalization of the results.

\section{Measuring instruments}

The following measuring instruments were used in this study.

\section{Biographical Questionnaire}

The questionnaire was designed to ascertain the personal information needed for the statistical analysis of the data.

\section{The Career Concepts Questionnaire (CCQ)}

The Career Concepts Questionnaire (CCQ) of Driver, Brousseau, Von Glinow and Prince (1980) was used. The questionnaire measures the preferences individuals have for specific career patterns (linear, spiral, expert and transitory) as well as the importance of a set of career decision factors or pattern motives in making career decisions. The questionnaire provides two sets of information. Firstly, the career pattern score which indicates the respondent's preference toward one of the four general career patterns and secondly, a career pattern motive score which illustrates the importance of the personal motives in Table 2 for the individual, and which is also an indication of the career pattern that the individual actually would have preferred.

The reliability and validity of the CCQ were examined by Coombs (1989). Positive correlations were found with the test-retest procedure. Research offered support for the fit or construct validity between basic descriptions of career patterns and key elements of those patterns. Overall, the results confirmed the integrity of the instrument to assess and identify individual career pattern identifications and the correlation of expected career decision factors (motives).

\section{The Myers-Briggs Type Indicator (MBTI)}

Form G, the standard form of the MBTI (Briggs \& Myers, 1997; Myers \& McCaulley, 1992), was used for this research project. The form $\mathrm{G}$ is a self-reporting instrument, consisting of items which measure individuals' preferences in regard to the basic functions of perception and judgment that enter into almost every behaviour. The items describe various types of easily recognised behaviours or reactions in various life settings. Responses indicate individuals' preferences in regard to the four scales or indices, Extraversion/Introversion (EI); Sensing/Intuition (SN); Thinking/Feeling (TF); and Judging/Perceiving (JP). The reported personality type indicates whether the individual has a preferred orientation towards the ST, SF, NF or NT personality type grouping. Extensive data presented by Myers and McCaulley (1992) confirm the validity and reliability of the MBTI, Form G.

\section{RESULTS}

\section{Statistical analysis}

The Chi-square was the chosen method of analysis to test for association between the categories of variables. The aim of the Chi-square technique is to test the statistical significance of the association between the mentioned categories, or put differently, to test whether membership of a given category on one dimension (e.g. the four career patterns) tend to be associated with membership of a given category on the other dimension (i.e. the four personality types). The data observations are displayed in $4 \times 4$ contingency tables as each of the two sets of variables had four levels to be tested for independence.

The analysis is part of the crosstabs routine in the Statistical Package for the Social Sciences (SPSS). The null hypothesis proposes no differences in distribution between each of the groups of variables, or that the differences obtained would be no different than what might be obtained by chance. If the computed $\mathrm{x}^{2}$ from the computer analysis exceeds the critical value from the $\mathrm{x}^{2}$ table, the null hypothesis will be rejected. If that occurs it will be concluded that the differences between 
each of the groups were not due to chance, that is, that the variables are not independent of each other.

Table 6 displays ideal career patterns and the related career pattern motives frequencies for the total sample. The horizontal row totals show the numbers and percentages of subjects who rated each of the four ideal career patterns most highly. 36\% of the sample rated the expert career pattern as the most desirable, followed by a preference for the linear career pattern $(28,8 \%)$ and the spiral career pattern $(26,4 \%)$.

The vertical row totals show the numbers and percentages of subjects who rated each of the four related sets of career pattern motives most highly. The majority of the sample (44\%) rated the expert pattern motives of security, expertise and competence as most important to them personally, followed by a preference for the spiral pattern motives of personal growth, creativity and developing others $(28 \%)$. The row totals are quite different from the column totals. The expert career pattern is rated as most ideal by the majority of the sample group, followed closely by the linear and spiral career patterns. Together, these three groups comprise $91,2 \%$ of the sample. However, this distribution clusters predominantly in firstly, the expert career pattern motives and secondly, in the spiral career pattern motives category. Together, these two groups comprise $72 \%$ of the total sample.

The frequency distribution of the four personality types (ST, SF, NF, NT) for the total sample group is displayed in Table 7 . The personality types are expressed as a percentage of the sample group in the table format. The data is only used to categorise the sample according to the four personality types, and therefore only frequencies and percentages are shown.

The majority of the sample clusters in the ST (Sensing-Thinking) personality type category $(71,2 \%)$, followed by a less strongly clustering in the NT (Intuition-Thinking) personality type category $(22,4 \%)$. The SF (Sensing-Feeling) and NF (Intuition-Feeling) personality types don't feature strongly ( $4 \%$ and $2,4 \%$ respectively).

The data reported in Table 7 indicates a predominant preference for career areas or fields that demand impersonal analysis of concrete facts with its step-by step logical process of reasoning from cause to effect, from premise to conclusion. Using technical skills and abilities with facts and objects are preferred (ST-types), followed by an interest to use abilities in theoretical and technical developments (NT-types). The STJ preference indicates predominant underlying work values such as technical orientation, security, stability, expertise. This is in line with the aforementioned career patterns observations. Both the ST personality types and expert career pattern share the underlying work values of expertise, security, and stability and a preference to using technical skills and abilities.

TABLE 6

FREQUENCY DISTRIBUTION OF THE CAREER PATTERNS AND THE RELATED CAREER PATTERN MOTIVES Career Pattern Motives

\begin{tabular}{|c|c|c|c|c|c|}
\hline \multicolumn{6}{|c|}{ Career Pattern Motives } \\
\hline & \multirow[b]{2}{*}{ Linear } & \multirow[b]{2}{*}{ Transitory } & \multirow[b]{2}{*}{ Expert } & \multicolumn{2}{|r|}{ Row Total } \\
\hline & & & & Spiral & $\%$ \\
\hline \multicolumn{6}{|l|}{ Ideal Career } \\
\hline \multicolumn{6}{|l|}{ Pattern: } \\
\hline Linear & 6 & 3 & 14 & 13 & 36 \\
\hline & & & & & $(28,8 \%)$ \\
\hline Transitory & 2 & 3 & 4 & 2 & 11 \\
\hline & & & & & $(8,8 \%)$ \\
\hline Expert & 1 & 8 & 23 & 13 & 45 \\
\hline & & & & & $(36,0 \%)$ \\
\hline Spiral & 6 & 6 & 14 & 7 & 33 \\
\hline & & & & & $(26,4 \%)$ \\
\hline Column Total & 115 & 20 & 55 & 35 & 125 \\
\hline$(\%)$ & $(12,0 \%)$ & $(16,0 \%)$ & $(44,0 \%)$ & $(28,0 \%)$ & $(100,0 \%)$ \\
\hline
\end{tabular}

TABLE 7

FREQUENCY DISTRIBUTION OF PERSONALITY TYPES

\begin{tabular}{|c|c|c|c|}
\hline \multicolumn{2}{|c|}{ Sensing Types } & \multicolumn{2}{|c|}{ Intuitives } \\
\hline Thinking & Feeling & Feeling & Thinking \\
\hline ST & SF & NF & NT \\
\hline$\underline{\mathrm{ISTJ}}$ & ISFJ & INFJ & INTJ \\
\hline n: 44 & $\mathrm{n}: 3$ & $\mathrm{n}: 0$ & $\mathrm{n}: 5$ \\
\hline$\% 35,2$ & $\% 2,4$ & $\% 0$ & $\% 4$ \\
\hline ISTP & ISFP & INFP & INTP \\
\hline$n: 3$ & $\mathrm{n}: 1$ & $\mathrm{n}: 1$ & $\mathrm{n}: 4$ \\
\hline$\% 2,4$ & $\% 0,8$ & $\% 0,8$ & $\% 3,2$ \\
\hline ESTP & ESFP & ENFP & ENTP \\
\hline n: 8 & $\mathrm{n}: 0$ & $\mathrm{n}: 2$ & n: 6 \\
\hline$\% 6,4$ & $\% 0$ & $\% 1,6$ & $\% 4,8$ \\
\hline ESTJ & ESFJ & ENFJ & ENTJ \\
\hline n: 34 & $\mathrm{n}: 1$ & $\mathrm{n}: 0$ & $\mathrm{n}: 13$ \\
\hline$\% 27,2$ & $\% 0,8$ & $\% 0$ & $\% 10,4$ \\
\hline TOTAL: 89 & 5 & 3 & 28 \\
\hline 71,2 & 4 & 2,4 & 22,4 \\
\hline
\end{tabular}

Total sample: $\mathrm{n}=125$

TABLE 8

CHI-SQUARE (TEST OF ASSOCIATION) FOR CAREER PATTERNS AND PERSONALITY TYPES (TOTAL SAMPLE)

\begin{tabular}{|c|c|c|c|c|c|c|c|c|c|c|}
\hline \multicolumn{11}{|c|}{ Personality Types } \\
\hline & \multicolumn{2}{|c|}{ ST } & \multicolumn{2}{|c|}{ SF } & \multicolumn{2}{|c|}{ NF } & \multicolumn{2}{|c|}{ NT } & \multicolumn{2}{|c|}{ Total } \\
\hline $\begin{array}{l}\text { Career } \\
\text { Patterns: }\end{array}$ & $\mathbf{n}$ & $\%$ & $\mathbf{n}$ & $\%$ & $\mathbf{n}$ & $\%$ & $\mathbf{n}$ & $\%$ & $\mathbf{n}$ & $\%$ \\
\hline Linear & 12 & 9,6 & 0 & 0 & 0 & 0 & 3 & 2,4 & 15 & 12,0 \\
\hline Transitory & 11 & 8,8 & 0 & 0 & 2 & 1,6 & 7 & 5,6 & 20 & 16,0 \\
\hline Expert & 45 & 36,0 & 2 & 1,6 & 0 & 0 & 8 & 6,4 & 55 & 44,0 \\
\hline Spiral & 21 & 16,8 & 3 & 2,4 & 1 & 0,8 & 10 & 8,0 & 35 & 28,0 \\
\hline TOTAL & 89 & 71,2 & 5 & 4,0 & 3 & 2,4 & 28 & 22,4 & 125 & 100,0 \\
\hline
\end{tabular}

The measure of association between the career patterns and personality types for the total sample $(n=125)$ is represented in table 8.

$x^{2}=15,7$

$d f=9$

$p=0,07$

$n=125$

10 out of $16(62,5 \%)$ of the valid cells have expected frequency less than 5,0

Minimum expected cell frequency $=0,360$.

At 9 degrees of freedom and $p=0,05$ the critical value from the $x^{2}$ table is 16,92 . The computed $x^{2}$ value from the computer analysis does not exceed the critical value and therefore the null hypothesis is not rejected. $x^{2}$ is however significant on $p=0,10(p<10)$.

TABLE 9

CHI-SQUARE (TEST OF ASSOCIATION) FOR CAREER PATTERNS AND PERSONALITY TYPES (GROUP WITH MATCHING IDEAL CAREER PATTERNS AND RELATED CAREER PATTERN MOTIVES)

\begin{tabular}{lrccccccccrr}
\hline \multicolumn{10}{c}{ Personality Types } \\
\hline \multicolumn{1}{c}{} & \multicolumn{1}{c}{ ST } & \multicolumn{1}{c}{ SF } & \multicolumn{1}{c}{ NF } & \multicolumn{2}{c}{ NT } & \multicolumn{2}{c}{ Total } \\
Career & $\mathbf{n}$ & $\mathbf{\%}$ & $\mathbf{n}$ & $\mathbf{\%}$ & $\mathbf{n}$ & $\mathbf{\%}$ & $\mathbf{n}$ & $\mathbf{\%}$ & $\mathbf{n}$ & $\mathbf{\%}$ \\
Patterns: & & & & & & & & & & \\
Linear & 4 & 10,3 & 0 & 0 & 0 & 0 & 2 & 5,1 & 6 & 15,4 \\
Transitory & 0 & 0 & 0 & 0 & 1 & 2,6 & 2 & 5,1 & 3 & 7,7 \\
Expert & 21 & 53,8 & 0 & 0 & 0 & 0 & 2 & 5,2 & 23 & 59,0 \\
Spiral & 4 & 10,3 & 1 & 2,6 & 0 & 0 & 2 & 5,1 & 7 & 17,9 \\
\hline TOTAL & $\mathbf{2 9}$ & $\mathbf{7 1 , 4}$ & $\mathbf{1}$ & $\mathbf{2 , 6}$ & $\mathbf{1}$ & $\mathbf{2 , 6}$ & $\mathbf{8}$ & $\mathbf{2 0 , 5}$ & $\mathbf{3 9}$ & $\mathbf{1 0 0 , 0}$
\end{tabular}

The measure of association between the career patterns and personality types for the group with matching ideal career patterns and true career patterns (or career pattern motives), $(\mathrm{n}=39)$ is represented in table 9 . 


$$
\begin{aligned}
& x^{2}=25,4 \\
& d f=9 \\
& p=0,003 \\
& n=39
\end{aligned}
$$

14 out of $16(87,5 \%)$ of the valid cells have expected frequency less than 5,0. Minimum expected cell frequency $=0,077$.

At 9 degrees of freedom and $p=0,05$ the critical value from the $x^{2}$ table is 16,92 . The computed $x^{2}$ value exceeds the critical value and therefore the null hypothesis is rejected.

\section{DISCUSSION AND CONCLUSION}

As displayed in Table 6 the discrepancies between the ideal career pattern frequencies and the related career pattern motives or true career patterns frequencies are noteworthy. Ideally, the two sets of frequencies should correspond closely. Subjects who rated the linear career pattern of career movement as most desirable, gave low ratings to the linear career pattern motives of power and achievement, and high ratings to the expert pattern motives of personal growth, creativity and developing others.

According to Brousseau and Driver (1994), the linear mismatch is a fairly common mismatch, known as the "false linear". The observations in Table 6 are in line with findings of a survey by Driver and Hoffman (1979), which indicated that many people whose primary identifications with the linear pattern, are actually "closet spirals". They seem to fall into two categories; namely: (1) those who truly prefer a linear career, but who identify secondarily with the spiral pattern; and (2) those who would prefer a spiral to a linear career, but who may not be aware of this because they have superficially accepted social norms favouring the linear career.

The data reported in Table 6 are also noteworthy in terms of the number of "false linears". The number of "false linears" in this sample group is 30 (or put differently, $83,3 \%$ of the subjects who identify primarily with the linear career pattern, secondarily identify themselves with non-linear values). The frequencies indicate that $75 \%$ of the subjects whose primary career pattern identification is linear, secondarily identify with either the expert $(38,9 \%)$ or the spiral $(36,1 \%)$ careers. This is an interesting observation, given the fact that according to Brousseau (1990), linear and expert patterns differ more fundamentally in values than do linear and spiral patterns.

The strong technical occupational orientation of both the management and professional groups could account for the strong identification with the expert career pattern. Similar mismatch patterns are observed for the spiral, expert and transitory career patterns.

Although mismatch patterns are also observed for the expert career pattern, the expert career pattern motives indicate the highest frequency correspondence to the expert career pattern. However, the match is far from perfect. The frequencies indicate that $25,6 \%$ of the total sample group can be termed as "closet experts" and $22,4 \%$ as "closet spirals". Overall, the sample group comprises of $24 \%$ "false linears"; $20,8 \%$ "false spirals"; 17,6\% "false experts" and 6,4\% "false transitories". Both "false linears" and "false spirals" tend to be predominantly "closet experts". Again, the strong technical occupational orientation of the sample group could account for the strong identification with expert career pattern.

Across the four ideal career patterns, only about one-third $(31,2 \%)$ of the respondents in the sample shows a congruent match between ideal career patterns and related career pattern motives. Schreuder (1998) found a similar result amongst a group of 188 South African managers.

The data reported in Table 8 show that the direction of the association is such that the ST-personality types are more likely to prefer the expert career pattern $(36,0 \%)$, followed by a preference for the spiral career pattern $(16,8 \%)$. Put differently, the proportion of ST-personality types that chooses the expert career pattern, is significantly higher than the NT, NF, SF, personality types that choose the expert career pattern. This observation is also in line with the theoretical postulation that a linkage does exist between the ST-personality types and the expert career pattern.

The NT-personality type seems to associate strongly with the spiral career pattern, as well as with the transitory career pattern. No association is observed for the SF- and NF- personality types. The observed association between the NTpersonality type and the spiral transitory career patterns is in line with the theoretical postulation that a linkage exists between these variables.

The observed association between the career patterns and personality types is significant on the 0,10 level $(p<0,10)$, but not on the 0,05 level $(p>0,05)$. This indicates a probable relationship between the career patterns and personality types. The data may not be reliable because of the small number of valid cells. The null hypothesis is thus not rejected on the $p \leq 0,10$ level. It can therefore be concluded that on the $p \leq 0,10$ level, the variables (career patterns and personality types) are not independent of each other.

The measured association between the career patterns and personality types (Table 9) reflects the following:

The direction of the association is again that the ST-personality types are more likely to prefer the expert career pattern. This observation is in line with the postulation that a relationship does exist between the ST-personality types and the expert career pattern. However, non-significant conclusions can be made with regard to the relationship between the other career patterns and personality types because of small cells.

Given the stated results, the research hypothesis (H1) is not rejected with regard to the test of association for the total sample $(p=0,10)$.

Based on the literature survey, it is recommended that both the Career Concepts Model and Personality Type theory be utilised as career counselling frameworks to ensure a process of self-enlightenment and informed career decision-making, especially with regard to career or work adjustment, or adaptation. Individuals can be facilitated to become more selfreliant in defining their career opportunities, through the stimulation of self-awareness of personal preferences, motives, values and needs versus what is socially desirable.

Additional research is needed to continue to examine the relationship between the career patterns and personality types. Stronger results may be obtained if a broader, more heterogenous pool of participants are explored. Research could be conducted in a variety of work settings and occupations to explore the presence of each career pattern, the related pattern motives and personality types in these different settings, especially within the South African context.

In conclusion then, the research has provided a glimpse into the ideal and true career patterns, and groupings of personality types of a small sample of managers and professional level people in a South African organisation. The set of data was unfortunately too small to draw significant conclusions in support of the research hypothesis. Nevertheless, the constructs and relationships that were revealed may provide additional bricks on the path to informed choices and insightful career planning for a future generation and should be seen as only the beginning of a stream of research which could prove to be fruitful. 


\section{REFERENCES}

Briggs, K.C. \& Myers, I.B. (1997). Myers-Briggs Type Indicator, Form G Booklet. Palo Alto: Consulting Psychologists Press, Inc.

Brooks, L. (1991). Career counselling methods and practice. In D. Brown \& L. Brooks (Eds.). Career choice and development: Applying contemporary theories to practice. San Francisco: JosseyBass Publishers.

Brousseau, K.R. (1990). Career dynamics in the baby boom and baby bust era. Journal of Organizational Change Management, 3(3), 46-57.

Brousseau, K.R. \& Driver, M.J. (1994). Enhancing informed choice: A career-concepts approach to career advertisement. Selections, Spring, 24-31.

Coombs, M. (1989). Measuring career concepts: An examination of the concepts, constructs, and validity of the CCQ. Phd Dissertation, University of Southern California, Los Angeles.

DeFillippi, R.J. \& Arthur, M.B. (1994). The boundaryless career: A competency-based perspective. Journal of Organizational Behaviour, 15, 307-24.

Driver, M.J. (1979). Career concepts and career management in organizations. In C.L. Cooper (Ed.). Behavioural problems in organisations, (pp. 79-139). Englewood Cliffs: PrenticeHall, Inc.

Driver M.J. \& Hoffman, R. (1979). Triggers for self-renewal. Paper presented at annual meeting of the Academy of Management, San Francisco.

Driver, M.J., Brousseau, K.R., Von Glinow, M.A. \& Prince, J.B. (1980). The Career Concept Questionnaire. Department of Management and Organization, University of Southern California, Los Angeles.

Driver, M.J. (1982). Career concepts - A new approach to career research. In R. Katz (Ed.). Career issues in human resources management. Englewood Cliffs: Prentice-Hall, Inc.

Driver, M.J. \& Coombs, M.W. (1983). Fit between career concepts, corporate culture and engineering productivity and morale. Enhancing engineering careers. Conference Record of the 1983 IEEE Conference on Careers, Palo Alto, California.

Driver, M.J. \& Sundby, D.Y. (1983). A construct validation analysis of the Career Concept Questionnaire. Paper presented at the Academy of Management Meeting Dallas, Texas.

Driver, M.J. (1985). Demographic and societal factors affecting the linear career crisis. Canadian Journal of Administrative Science, 2(21), 245-263.

Driver, M.J. \& Brousseau, K.R. (1988). Four careerconcepts. Santa Monica: Decision Dynamics Corporation.

Galbraith, J. (1993). Organizing for the future. San Francisco: Jossey-Bass.

Ghoshal, S. \& Bartlett, C.A. (1997). The individualized corporation: A fundamentally new approach to management. London: Heinemann.

Handy, C. (1989). The future of work. Oxford: Basil Blackwell.

Hendrickz, P.T. (1987). Loopbaanbeplanning en-ontwikkeling vir data-verwerkingspersoneel met spesifieke verw ysing na stel- selontwikkeling en rekenaarbediening. Unpublished master's thesis, University of Pretoria, Pretoria.

Hiltrop, J. (1995). The changing psychological contract: The human resource challenge of the 1990's. European Management Journal, 13(3), 286-294.

Holland, J.L. (1985). Making vocational choices: A theory of vocational personalities and work environments. Englewood Cliffs: Prentice Hall, Inc.

Jung, C.G. (1990). Psychological types. Princeton: Princeton University Press.

Kummerow, J.M. (1991). Using the Strong Interest Inventory and the Myers-Briggs Type Indicator together in career counselling. In J. Kummerow (Ed.). New directions in career planning and the workplace. Palo Alto: Consulting Psychologists Press, Inc.

Lawrence, G. (1993). People types and tiger stripes: A practical guide to learning styles. Gainesville: Centre for the Applications of Psychological Type.

Miles, R.E. \& Snow C.C. (1994). Fit, failure and the hall of fame: How companies succeed or fail. New York: Free Press.

Mirvis, P. \& Hall, D. (1994). Psychological success and the boundaryless career. Journal of Organizational Behaviour, 15, 365-380.

Montross, D.H. \& Shinkman, C.J. (1992). Career development: Theory and practice. New York: Charles C. Thomas Publishers.

Moss Kanter, R. (1994). Change in the global economy: An interview with Rosabeth Moss Kanter. European Management Journal, 12 (1), 1-9.

Myers, I.B. (1980). Gifts differing. Palo Alto: Consulting Psychologists Press, Inc.

Myers, I.B. \& McCaulley, M.H. (1992). Manual: A guide to the development and use of the Myers-Briggs Type Indicator. Palo Alto: Consulting Psychologists Press, Inc.

Olson, T. (1979). Career concepts and decision styles. Paper presented at The Academy of Management Meeting, Atlanta.

Peiperl, M.A.; Arthur, M.B.; Goffee, R. \& Morris, T. (2000). Career frontiers: New conceptions of working lives. New York: Oxford University Press.

Prince, J.B. (1979). An investigation of career concepts and career anchors. Paper presented at the Western Academy of Management Meeting, Portland.

Savickas, M.L. (1994). Convergence prompts theory renovation, research unification, and practice coherence. In M.L. Savickas \& R.W. Lent (Eds.). Convergence in career development theories, (pp. 235-257). Palo Alto: Consulting Psychologists Press, Inc.

Schein, E.H. (1975). How "career anchors" hold executives to their career paths. Personnel, 52(3), 11-24.

Schreuder, A.M.G. (1998). Die loopbaanpatrone van SuidAfrikaanse bestuurders. Journal of Industrial Psychology, 24(1), 5-9.

Weick, K.E. (1996). Enactment and the boundaryless career: Organizing as we work. In M.B. Arthur \& D.M. Rousseau (Eds.). The boundaryless career: A new employment principle for a new organizational era. New York: Oxford University Press. 